\title{
TAHAP DEFINISI DALAM FOUR-D MODEL PADA PENELITIAN RESEARCH \& DEVELOPMENT (R\&D) ALAT PERAGA EDUKASI ULAR TANGGA UNTUK MENINGKATKAN PENGETAHUAN SAINS DAN MATEMATIKA ANAK USIA 5-6 TAHUN
}

\author{
1*Birru Muqdamien; ${ }^{2}$ Umayah; ${ }^{3}$ Juhri; ${ }^{4}$ Desty Puji Raraswaty, \\ ${ }^{1234}$ UIN Sultan Maulana Hasanuddin Banten \\ 1birru.aishiteru888@gmail.com;ㄹmayah@uinbanten.ac.id; 3juhri@uinbanten.ac.id; \\ ${ }^{4}$ destypujiraras@gmail.com
}

\begin{abstract}
Educational play tools (APE) have become a necessity during AUD learning because they are full of educational materials that can be adapted to their growth. This development research aims to produce a product in the form of a ladder snake APE in improving the cognitive abilities of children aged 5-6 years in the fields of science and mathematics at RA Mafatihul Ulum, Serang City, Banten Province. This type of research involves using a number of methods and types of research and going through various stages of research sessions, so each session is carried out to achieve its respective objectives. The Four-D Model development model suggested by Sivasailam This model consists of 4 development stages, namely; Define (defining), Design (Design), Develop (development) and Disseminate (deployment). The definition stage offered in the 4D model consists of several stages of analysis, namely curriculum analysis, needs analysis, student analysis, concept analysis, task analysis and formulation of learning objectives.
\end{abstract}

Keywords: Educational play tools, Research \& Development, early Childhood, science and mathematics

\begin{abstract}
Abstrak
Alat permainan edukatif (APE) telah menjadi sebuah kebutuhan saat pembelajaran AUD karena sarat dengan materi pendidikan yang bisa disesuaikan dengan pertumbuhan mereka. Penelitian pengembangan ini bertujuan untuk menghasilkan suatu produk berupa sebuah APE ular tangga dalam meningkatkan kemampuan kognitif anak usia 5-6 tahun bidang sains dan matemtika di RA Mafatihul Ulum Kota Serang Provinsi Banten. Riset jenis ini melibatkan penggunaan sejumlah metode dan jenis riset dan melewati berbagai sesi tahapan riset, maka setiap sesi ini dilakukan untuk mencapai tujuannya masing-masing Model pengembangan perangkat Four-D Model disarankan oleh Sivasailam Model ini terdiri dari 4 tahap pengembangan yaitu; Define (pendefinisian), Design (Perancangan), Develop (pengembangan) dan Disseminate (penyebaran). Dalam tahap pendefinisian yang ditawarkan pada model 4D terdiri dari beberapa tahap analisis, yaitu analisis kurikulum, analisis kebutuhan, analisis siswa, analisis konsep, analisis tugas dan perumusan tujuan pembelajaran.

Kata Kunci: Alat Peraga edukasi, Penelitian pengembangan, Aandak usia dini, pegnentahuan sains dan matematika
\end{abstract}

\section{PENDAHULUAN}

Alat permainan edukatif (APE) telah menjadi sebuah kebutuhan strategik dalam pembelajaran anak usia dini karena sarat dengan muatan pendidikan yang sesuai dengan pertumbuhan mereka (Hijriati, 2017; Tintia, 2018). Menurut Mayke Sugianto APE adalah permainan yang sengaja dirancang secara khusus untuk kepentingan pendidikan. Sedangkan Zaman \& Hernawan (2014, hal. 63) menyatakan bahwa APE untuk anak usia dini adalah alat permainan yang dirancang untuk tujuan meningkatkan aspek-aspek perkembangan anak usia dini. Di sinilah konteks dan inti permainan yang sesungguhnya, yakni sebagai media atau objek yang memberikan efek kesenangan dan mendukung terwujudnya motivasi positif pada 
siswa. Dengan kata lain, permainan sebagai upaya mempengaruhi psikologis siswa (Imroatun, 2014).

Alat permainan dapat dikategorikan sebagai alat permainan edukatif untuk anak TK jika memiliki ciri-ciri tertentu. Zaman \& Hernawan (2014, hal. 63) mensyaratkan permainan itu diajukan untuk anak usia dini; berfungsi mengembangkan aspek-aspek perkembangan anak usia dini; dapat digunakan berbagai cara, bentuk dan untuk bermacam tujuan aspek pengembangan atau bermanfaat multiguna; keamanan bagi anak; perancangan bertujuan mendorong aktivitas dan kreativitas anak usia dini; sifatnya konstruktif atau ada sesuatu yang dihasilkan.

Kunci pertama dalam suatu permainan dapat dilakukan edukatif adalah permainan tersebut memiliki nilai guna, efektivitas dan evisiensi yang mengarahkan proses mendidik secara positif. Hal ini dapat terjadi jika suatu permainan dapat dikontrol dan digunakan dengan tepat. Sebab permainan akan berdampak atau memberikan pengaruh negatif apabila tidak ada latar belakang "mendidik" atau mengajak dan mengarahkan sisiwa menuju kehidupannya yang lebih baik. Di sinilah konteks dan inti permainan yang sesungguhnya, yakni sebagai media atau objek yang memberikan efek kesenangan dan mendukung terwujudnya motivasi positif pada sisiwa (Fathurohman, 2017; Mujib \& Rahmawati, 2011, hal. 30).

Penggunaan alat permainan edukatif yang sesuai dengan tingkat perkembangan anak dapat membantu guru dalam mengembangkan seluruh kemampuan dasar Anak Usia Dini (AUD). Dalam pembelajaran dibutuhkan hubungan komunikasi yang baik antar guru dengan sisiwa untuk meningkatkan hasil pembelajaran yang optimal dan proses pembelajaran bisa berjalan dengan efektif. Untuk menunjang hasil yang baik, dibutuhkan sebuah media untuk membantu guru dalam menyampaikan materi yang diajarkan agar dalam proses pembelajaran tidak terkesan membosankan dan tidak menarik. Akan tetapi penggunaan media harus sesuai denagan karakteristik siswa dengan menyesuaikan bahan apa yang sekiranya dapat mencuri perhatian siswa.

salah satu manfaat alat permainan edukatif adalah membantu pertumbuhan fisik dan seluruh aspek perkembangan anak terutama aspek kognitif. Alat permainan edukatif (APE) untuk anak PAUD selalu dirancang dengan pemikiran yang mendalam tentang karakteristik anak dan disesuaikan dengan rentang usia anak PAUD. Contohnya dalam alat peraga edukasi ular tangga, dimana permainan ini dapat mengasah kemampuan berbagai aspek pada anak usia dini terutama dalam aspek kognitif. 
Salah satu aspek perkembangan yang menjadi perhatian pada AUD adalah aspek perkembangan koginitif. Aspek ini berkaitan perkembangan mereka di bidang sains dan matematika.

Tabel 1

Standar Tingkat Pencapaian Kognitif Anak Usia 5-6 Tahun

Permen Diknas No. 58 Tahun 2009

\begin{tabular}{|c|c|}
\hline $\begin{array}{r}\text { Li } \\
\text { Perke }\end{array}$ & Tingkat Pencapaian usia 5-6 Tahun \\
\hline $\begin{array}{l}\text { KOGNITIF } \\
\text { A. Pengetahuan } \\
\text { Umum dan } \\
\text { Sains }\end{array}$ & $\begin{array}{l}\text { 1. Mengklasifikasikan benda berdasarkan fungsi. } \\
\text { 2. Menunjukkan aktivitas yang bersifat } \\
\text { eksploratif dan menyelidik (Seperti: apa yang } \\
\text { terjadi ketika air ditumpahkan). } \\
\text { 3. Menyusun perencanaan kegiatan yang akan } \\
\text { dilakukan } \\
\text { 4. Mengenal sebab-akibat tentang lingkungannya } \\
\text { (angin bertiup menyebabkan daun bergerak, } \\
\text { air dapat menyebabkan sesuatu menjadi } \\
\text { basah). } \\
\text { 5. Menunjukkan inisiatif dalam memilih tema } \\
\text { permainan (Seperti: ayo kita bermain pura- } \\
\text { pura seperti burung). } \\
\text { 6. Memecahkan masalah sederhana dalam } \\
\text { kehidupan sehari-hari. }\end{array}$ \\
\hline $\begin{array}{l}\text { B. Konsep } \\
\text { Bentuk, } \\
\text { Warna, } \\
\text { Ukuran dan } \\
\text { Pola }\end{array}$ & $\begin{array}{l}\text { 1. Mengenal perbedaan berdasarkan ukuran: } \\
\text { lebih dari, kurang dari dan paling/ter. } \\
\text { 2. Mengklasifikasikan benda berdasarkan warna, } \\
\text { bentuk dan ukuran ( } 3 \text { variasi). } \\
\text { 3. Mengklasifikasikan benda yang lebih banyak } \\
\text { ke dalam kelompok yang sama atau kelompok } \\
\text { yang sejenis atau kelompok berpasangan yang } \\
\text { lebih dari } 2 \text { variasi. } \\
\text { 4. Mengenal pola ABCD-ABCD. } \\
\text { 5. Mengurutkan benda berdasarkan ukuran dari } \\
\text { paling kecil ke paling besar atau sebaliknya. }\end{array}$ \\
\hline $\begin{array}{l}\text { C. Konsep } \\
\text { Bilangan, } \\
\text { Lambang } \\
\text { Bilangan dan } \\
\text { Huruf } \\
\end{array}$ & $\begin{array}{l}\text { 1. Menyebutkan lambang bilangan } 1-10 \\
\text { 2. Mencocokkan bilangan dengan lambang } \\
\text { bilangan. } \\
\text { 3. Mengenal berbagai macam lambang huruf } \\
\text { vokal dan konsonan. }\end{array}$ \\
\hline
\end{tabular}

Sumber: (Peraturan Menteri Pendidikan Nasional Nomor 58 Tahun 2009 tentang Standar Pendidikan. Anak Usia Dini, 2009)

Penelitian Skripsi R\&D oleh Permadi (2018) yang berjudul "Pengembangkan Permainan Ular Tangga Untuk Meningkatkan Kemampuan Berhitung Permulaan Anak Usia 5-6 Tahun". Penelitian ini juga menghasilkan produk berupa sebuah permainan "Ular Tangga" yang layak digunakan untuk dijadikan sebuah pembelajaran untuk mengembangkan 
kemampuan berhitung anak usia 5-6 tahun sesuai dengan prosedur. Pengembangan alat peraga "Ular Tangga" ini menggunakan penelitian model pengembangan Baker dan Schultz. Hasil penelitian yang dilakukan oleh Handari Permadi diujikan kepada dua para ahli yaitu ahli media dan ahli materi. Kemudian melakukan uji coba lapangan secara terbatas kepada lima anak. Dari hasil uji coba expert review ahli media memperoleh nilai rata-rata kualitas media 3,1. Selanjutnya ahli materi memperoleh nilai rata-rata kualitas materi dengan jumlah skor 4. Selanjutnya dari hasil uji coba lapangan memperoleh nilai rata-rata 3,3 dengan skala penilaian 1 sampai 4 yang berarti kualitas permainan ular tangga ini sangat sesuai. Perbandingan penelitian Handari Permadi dengan penelitian yang sedang dilakukan adalah sama-sama di variabel $X$ tentang permainan ular tangga hanya saja yang membedakan di variabel Y peneliti mengenai kemampuan kognitif anak usia 5-6 tahun.

Penelitian Skripsi PTK yang berjudul "Meningkatkan Kemampuan Kognitif Melalui Permainan Ular Tangga Anak Kelompok A TK Dharma Wanita Sumberjo Kecamatan Kademangan Kabupaten Blitar Tahun Pelajaran 2014/2015" (Handayani, 2015). Penelitian ini bertujuan untuk memperoleh data tentang kemampuan kognitif pengenalan angka pada anak kelompok A TK Dharma Wanita sebelum diadakan tindakan dan bertujuan untuk melakukan tindakan berupa penerapan media permainan ular tangga untuk meningkatkan kemampuan kognitif pengenalan angka pada anak kelompok A TK Dharma Wanita. Hasil penelitian yang dilakukan oleh Nanik Handayani pada penilaian prosentase ketuntasan belajar anak dalam kemampuan kognitif berjumlah 15 anak pada Siklus I berjumlah 40\%, Siklus II berjumlah $60 \%$ dan Siklus III berjumlah $86,7 \%$. Dengan perolehan hasil penelitian di atas maka dapat disimpulkan bahwa hipotesis "Penerapan Permainan Ular Tangga Ikan Dapat Meningkatkan Kemampuan Kognitif dalam Hal Mengenal Warna Pada Anak Kelompok A TK Dharma Wanita Sumberjati Kecamatan Kademangan Kabupaten Blitar" diterima. sedangkan untuk perbandingan penelitian Nanik Handayani dengan penelitian yang sedang dilakukan adalah sama-sama di variabel $\mathrm{X}$ dan $\mathrm{Y}$ yang membedakan peneliti menggunakan subyek anak usia 5-6 tahun yaitu kelompok B.

Astutik ( 2017) Penelitian ini bertujuan untuk menghasilkan dengan model penelitian PTK yang bertujuan untuk mengetahui kelayakan alat permainan edukatif Wayang Ular Tangga (Walarta) untuk pengenalan nilai-nilai karakter pada anak TK kelompok serta mengetahui keefektifan alat permainan edukatif Wayang Ular Tangga (Walarta) untuk pengenalan nilai-nilai karakter pada anak TK kelompok B. Perbandingan penelitian Khoirotunnisa dengan penelitian yang sedang dilakukan adalah sama-sama di variabel $\mathrm{X}$ 
tentang permainan ular tangga hanya saja yang membedakan di variabel Y peneliti mengenai tentang kemampuan kognitif anak usia 5-6 tahun.

Dalam Penelitian e-Journal Pendidikan Anak Usia Dini dengan metode penlitian PTK yang dilakukan oleh Istri Ratna Dewi et al. (2016), yang berjudul "Penerapan Metode Bermain Melalui Permainan Ular Tangga Untuk Meningkatkan Perkembangan Kognitif Pada Anak Kelompok A." Hasil penelitian Istri Ratna dewi, dkk., pada siklus I sebesar 65,00\% yang berada pada kriteria "sedang", pada siklus II mengalami peningkatan sebesar 85,00\% yang berada pada kriteria tinggi. Dapat disimpulkan bahwa penerapan metode bermain melalui permainan ular tangga dapat meningkatkan perkembangan kognitif pada anak kelompok A semester II di PAUD Candra Kaih Denpasar Tahun Pelajaran 2015/2016. Perbandingan penelitian Khoirotunnisa dengan penelitian yang sedang dilakukan adalah sama-sama di variabel $\mathrm{X}$ dan $\mathrm{Y}$ hanyan saja membedakan subyek penelitian, peneliti melakukan kepada anak usia 5-6 tahun.

\section{METODE PENELITIAN}

Model penelitian ini adalah penelitian dan pengembangan Research and Development (R\&D). R\&D adalah suatu proses atau langkah-langkah untuk mengembangkan suatu produk baru atau menyempurnakan yang telah ada yang dapat dipertanggungjawabkan (Sukmadinata, 2011, hal. 164). R\&D merupakan metode penelitian yang digunakan untuk menghasilkan produk tertentu, dan menguji keefektifan produk tersebut (Haryati, 2013). Metode R\&D adalah metode penelitian yang menghasilkan inovasi baik suatu produk baru atau mengembangkan produk yang sudah ada untuk lebih menarik yang sesuai dengan tujuan pembelajaran dari pokok bahasan tertentu. Teknik analisis data yang dilakukan adalah menggunakan teknik analisis kuantitatif dan deskriptif kualitatif. Analisis kuantitatif digunakan mengetahui validitas instrumen produk APE Ular Tangga dan mengestimasi reliabilitas instrumen. Analisis deskriptif kualitatif digunakan untuk memaparkan hasil pengembangan produk berupa APE Ular Tangga, mengujinya pada tingkat validasi dan kelayakan produk untuk diimplementasikan dalam meningkatkan kemampuan kognitif anak usia 5-6 tahun. Data dianalisis oleh pakar/ahli, praktisi dan pengguna APE.

Model pengembangan dapat diartikan sebagain dasar yang digunakan dalam mengembangkan suatu produk yang akan dihasilkan. Model pengembangan juga dapat diartikan sebagai upaya memperluas untuk membawa suatu produk kepada produk yang lebih sempurna. Penelitian dirancang dengan mengggunakan model pengembangan 4-D (Four-D Models). Model pengembangan perangkat Four-D Model disarankan oleh Sivasailam Model 
ini terdiri dari 4 tahap pengembangan yaitu; Define (pendefinisian), Design (Perancangan), Develop (pengembangan) dan Disseminate (penyebaran) (Sugiyono, 2016, hal. 37).

Langkah-langkah atau prosedur di atas dapat digambarkan pada bagan sebagai berikut.



Gambar 1

Prosedur Pengembangan Model 4D

Penelitian ini dibatasi pada tahap awal yaitu pengidentifikasian atau definisi. karena model yang dikembangkan adalah model hipotetik sehingga tahapan yang dilakukan hanya 3 langkah/tahapan dari yang keseluruhan.

\section{HASIL TAHAP DEFINISI}

Dalam tahap pendefinisian terdiri dari beberapa tahap analisis, yaitu analisis kurikulum, analisis kebutuhan, analisis siswa, analisis konsep, analisis tugas dan perumusan tujuan pembelajaran. Tahapan tersebut dijelaskan sebagai berikut: 


\section{a. Analisis kurikulum}

Berdasarkan wawancara dengan guru di RA Mafatihul Ulum, pembelajaran yang selama ini dilakukan oleh guru di dalam kelas dengan melibatkan siswa bersifat monoton karena kurangnya media pembelajaran yang mendukung kegiatan proses pembelajaran di dalam kelas serta proses kegiatan pembelajaran di dalam kelas lebih terfokuskan kepada buku LKS atau buku yang bersumber dari Yayasan. Hal ini mengabitkan sisiwa kurang aktif dalam pelaksanaan proses pembelajaran di dalam kelas (wawancara Maimunah, 2019).

Kurikulum 2013 yang salah satunya berlandaskan pembelajaran kontekstual yang akan menghasilkan insan Indonesia yang produktif, kreatif, inovatif, efektif, melalui penguatan sikap, keterampilan dan pengetahuan yang terintegrasi. Dalam hal ini pengembangan kurikulum difokuskan pada meningkatkan kemampuan kognitif anak usia dini.

Untuk menunjang keberhasilan terlaksananya kurikulum 2013 tersebut yaitu dengan menggunakan metode bermain. Sehingga dengan metode bermain ini dapat membantu tercapainya proses kegiatan pembelajaran dikarenakan anak usia dini lebih menyukai bermain sambil belajar. Jadi siswa diharapkan aktif dalam kegiatan pembelajaran terutama dalam pengembangan APE ular tangga. Dengan menerapkan metode pembelajaran bermain sambil belajar diharapkan:

1) Pembelajaran tidak bersifat monoton;

2) Pada permainan ini dapat meningkatkan kemampuan kognitif anak usia dini;

3) Melatih kognitif siswa saat menjumlahkan mata ular saat dadu keluar;

4) Siswa dapat menyelasaikan teka-teki yang ada di setiap kotak ular tangga;

5) Permainan ini sangat efektif untuk mengulang pembelajaran yang telah diberikan.

Untuk melaksanakan pengembangan APE ular tangga, diperlukan perangkat yang mendukung kegiatan tersebut. Oleh karena itu, perlu dikembangkan APE ular tangga yang baik dengan didukung oleh instrumen penilaian validator dan intrumen perkembangan kognitif siswa.

1. Analisis awal-akhir

Berdasarkan hasil observasi dan analisis terhadap kegiatan pembelajaran yang mendukung di kelas B Al-Kautsar RA Mafatihul Ulum, menunjukkan bahwa selama ini sekolah tersebut kurangnya media pembelajaran yang mendukung kegiatan pembelajaran dalam meningkatkan berbagai aspek perkembangan pada anak usia dini. Media pembelajaran yang dilakukan oleh guru bersifat pengulangan sehingga anak merasa bosan karena tidak 
adanya alat permainan edukatif yang menarik dalam proses kegiatan pembelajaran (observasi, 2019)

2. Analisis pembelajar

Analisis pembelajar merupakan telaah karakteristik siswa yang meliputi kemampuan, latar belakang, pengetahuan dan tingkat perkembangan kognitif siswa. Peneliti telah melakukan observasi pada aspek perkembangan kognitif siswa kelompok B Al-Kautsar di RA Mafatihul Ulum. Dari segi karakteristik siswa kelompok B Al-Kautsar di RA Mafatihul Ulum rata-rata berumur 5,5-7 tahun. Jika dikaitkan dengan tahap perkembangan kognitif menurut Piaget, maka anak usia 5-6 tahun pada tahap ini adalah anak sudah mampu memecahkan masalah, berfikir logis dan matematis serta memiliki pengetahuan dan informasi yang cukup sesuai dengan tahap perkembangan mereka.

Berdasarkan hasil wawancara dengan Ibu Maimunah sebagai guru ahli bidang anak usia dini kelompok B AL-Kautsar di RA Mafatihul Ulum diperoleh informasi bahwa siswa di kelas tersebut adalah siswa yang sangat aktif terhadap kemampuan kognitif siswa. Dilihat dari kemampuan akademik siswa tersebut mereka memang sudah menggunakan metode pembelajaran bermain sambil belajar hanya saya media pembelaharan yang mereka gunakan masih minim sehingga anak merasa cepat bosan dalam proses kegiatan pembelajaran. Jadi dengan menggunakan APE ular tangga ini dengan sesuai tema pembelajaran "alam semesta" dapat meningkatkan kemampuan kognitif bagi siswa (wawancara Maimunah, 2019).

3. Analisis tugas

Rincian analisis tugas ini untuk tema pembelajaran "alam semesta" yang merujuk pada kompetensi inti dan kompetensi dasar sesuai dengan indikator. Hasil analisis tugas dapat dilihat pada.

Tabel 2

Analisis Tugas Tema Pembelajaran "Alam Semesta" Pada APE Ular Tangga

\begin{tabular}{|c|l|}
\hline No. & \multicolumn{1}{|c|}{ Jenis Kegiatan } \\
\hline 1. & "Start" berawal dari anak memulai kegiatan \\
\hline 2. & $\begin{array}{l}\text { a. Anak menyebutkan angka 2 huruf "B" "b" dan kata } \\
\text { "Bumi" } \\
\text { b. Anak mendefinisikan gambar Bumi }\end{array}$ \\
\hline 3. & Anak menyebutkan warna-warna pelangi \\
\hline 4. & $\begin{array}{l}\text { a. Anak mendefinisikan gambar bulan } \\
\text { b. Anak menjumlah gambar bulan }\end{array}$ \\
\hline 5. & Anak menyebutkan ciptaan matahari, bintang dan bulan \\
\hline
\end{tabular}




\begin{tabular}{|c|l|}
\hline 6. & $\begin{array}{l}\text { a. Anak mendefinisikan gambar bintang dan bulan } \\
\text { b. Anak menyebutkan angka jarum jam yang ada pada di } \\
\text { gambar bintang dan bulan }\end{array}$ \\
\hline 7. & Anak mendefinisikan gambar rumah kebakaran \\
\hline 8. & $\begin{array}{l}\text { Anak mendefinisikan gambar anak sedang membuang } \\
\text { sampah pada tempatnya }\end{array}$ \\
\hline 9. & Anak menjumlahkan gambar bintang \\
\hline 10. & $\begin{array}{l}\text { a. Anak mendefinisikan gambar banjir } \\
\text { b. Anak menyebutkan kata"Banjir" }\end{array}$ \\
\hline 11. & Anak menyanyikan lagu bintang kecil \\
\hline 12. & Anak menyebutkan nama-nama kota \\
\hline 13. & Anak mendefinisikan gambar pendesaan \\
\hline 14. & Anak menyebutkan angka 14 \\
\hline 15. & $\begin{array}{l}\text { Anak turun ke Angka 7 dikarenakan bermain api di dalam } \\
\text { rumah }\end{array}$ \\
\hline 16. & $\begin{array}{l}\text { Anak turun ke angka 8 dikarenakan membuang sampah } \\
\text { sembarangan }\end{array}$ \\
\hline 17. & Anak mendefiniskan gambar bencana alam \\
\hline 18. & Anak mendefiniskan gambar perkotaan \\
\hline 19. & $\begin{array}{l}\text { a. Anak mendefiniskan gambar tsunami } \\
\text { b. Anak menyebutkan kata "Tsunami” }\end{array}$ \\
\hline 20. & Anak berhasil menyelesaikan permainan ular tangga \\
\hline
\end{tabular}

\section{Analisis konsep}

Analisis ini dilakukan untuk mengidentifikasi konsep-konep utama yang akan dikembangkan pada APE ular tangga yaitu dengan membuat konsep pembuatan APE ular tangga sesuai dengan tema pembelajaran di sekolah.

\section{Penutup}

Berdasar pada model langkah-langkah Thiagarajan, proses definisi menghasilkan perumusan tujuan pembelajaran yang diperoleh dengan Kompetensi inti dan Kompetensi dasar kurikulum 2013, yaitu seperti pada tabel di bawah ini. 
Tabel 3

Perumusan Tujuan Pembelajaran Di RA Mafatihul Ulum

\begin{tabular}{|l|l|}
\hline No. & \multicolumn{1}{|c|}{ Tujuan Pembelajaran } \\
\hline 1. & Anak mampu mengawali permainan \\
\hline 2. & $\begin{array}{l}\text { a. Anak mampu menyebutkan angka } 2 \text { huruf Bb dan kata } \\
\text { "Bumi" } \\
\text { b. Anak mampu mendefinisikan gambar Bumi }\end{array}$ \\
\hline 3. & Anak mampu menyebutkan warna-warna pelangi \\
\hline 4. & $\begin{array}{l}\text { a. Anak mampu mendefinisikan gambar bulan } \\
\text { b. Anak mampu menjumlah gambar bulan }\end{array}$ \\
\hline 5. & $\begin{array}{l}\text { Anak mampu menyebutkan ciptaan matahari, bintang dan } \\
\text { bulan }\end{array}$ \\
\hline 6. & $\begin{array}{l}\text { a. Anak mampu mendefinisikan gambar bintang dan } \\
\text { bulan }\end{array}$ \\
\hline 7. & $\begin{array}{l}\text { Anak mampu mendefinisikan gambar rumah kebakaran } \\
\text { Anada mampu menyebutkan angka jarum jam yang ada }\end{array}$ \\
\hline 8. & $\begin{array}{l}\text { Anak mampu mendefinisikan gambar anak } \\
\text { membuang sampah pada tempatnya }\end{array}$ \\
\hline 9. & Anak mampu menjumlahkan gambar bintang \\
\hline 10. & $\begin{array}{l}\text { a. Anak mampu mendefinisikan gambar banjir } \\
\text { b. Anak mampu menyebutkan kata"Banjir" }\end{array}$ \\
\hline 11. & Anak mampu menyanyikan lagu bintang kecil \\
\hline 12. & Anak mampu menyebutkan nama-nama kota \\
\hline 13. & Anak mampu mendefinisikan gambar pendesaan \\
\hline 14. & Anak mampu menyebutkan angka 14 \\
\hline 15. & Anak mampu melakukan perintah \\
\hline 16. & Anak mampu melakukan perintah \\
\hline 17. & Anak mampu mendefiniskan gambar bencana alam \\
\hline 18. & Anak mampu mendefiniskan gambar perkotaan \\
\hline 19. & $\begin{array}{l}\text { a. Anak mampu mendefiniskan gambar tsunami } \\
\text { b. Anak mampu menyebutkan kata "Tsunami" }\end{array}$ \\
\hline 20. & Anak mampu menyelesaikan permainan ular tangga \\
\hline
\end{tabular}

\section{Daftar Pustaka}

Astutik, K. D. (2017). Pengembangan Alat Permainan Edukatif Wayang Ular Tangga (Walarta) Untuk Pengenalan Nilai-nilai Karakter Pada Anak TK Kelompok B. Pendidikan Guru PAUD S-1, 6(3), 289-299.

Fathurohman, O. (2017). Hakikat Bermain Dan Permainan Anak Usia Dini Di Pendidikan Anak Usia Dini (PAUD). aṣ-șibyān: Jurnal Pendidikan Anak Usia Dini, 2(1), 27-36.

Handayani, N. (2015). Meningkatkan Kemampuan Kognitif Melalui Permainan Ular Tangga Anak Kelompok A Tk Dharma Wanita Sumberjo Kecamatan Kademangan Kabupaten Blitar Tahun Pelajaran 2014/2015. Universitas Nusantara PGRI Kediri.

Haryati, S. (2013). RESEARCH AND DEVELOPMENT (R\&D) SEBAGAI SALAH SATU 
MODEL PENELITIAN DALAM BIDANG PENDIDIKAN.

Hijriati. (2017). Peranan Dan Manfaat Ape Untuk Mendukung Kreativitas AUD. Bunayya: Jurnal Pendidikan Anak, 3(2), 59-69.

Imroatun, I. (2014). Permainan Tradisional Sebagai Pembelajaran Kecakapan Sosial Bagi Anak Usia Dini. Jurnal Sains Psikologi, 3(1), 1-11.

Istri Ratna Dewi, A., Semara Putra, D. K. N., \& Nyoman Wirya, I. (2016). PENERAPAN METODE BERMAIN MELALUI PERMAINAN ULAR TANGGA UNTUK MENINGKATKAN PERKEMBANGAN KOGNITIF PADA ANAK KELOMPOK A. Jurnal Pendidikan Anak Usia Dini Undiksha, 4(2). https://doi.org/10.23887/PAUD.V4I2.7625

Peraturan Menteri Pendidikan Nasional Nomor 58 Tahun 2009 tentang Standar Pendidikan. Anak Usia Dini, (2009).

Mujib, F., \& Rahmawati, N. (2011). Metode Permainan-Permainan Edukatif dalam Belajar Bahsa Arab. Diva Press.

observasi. (2019).

Permadi, H. (2018). Pengembangkan Permainan Ular Tangga Untuk Meningkatkan Kemampuan Berhitung Permulaan Anak Usia 5-6 Tahun. UNJ.

Sugiyono. (2016). Metode Penelitian Kuantitatif, Kualitatif, Dan RnD. ALFABETA.

Sukmadinata, N. S. (2011). Metode Penelitian Pendidikan. Remaja Rosda Karya.

Tintia, N. (2018). Penggunaan alat permainan edukatif lego dala mengembangkan kreativitas anak usia 3-4 tahun di creativkids and U Art Bandar Jaya Timur. In Universitas Negeri Raden Intan Lampung. FTK UIN Raden Intan Lampung.

wawancara Maimunah. (2019).

Zaman, B., \& Hernawan, A. H. (2014). Media dan Sumber Belajar TK. Penerbit Universitas Terbuka. 